\title{
COMMON RIGHT, DUE PROCESS AND ANTITRUST
}

\author{
Walton Hamilton*
}

The Sherman Act ${ }^{1}$ is the great charter of American industry. ${ }^{2}$ It is the elementary ordinance about which the pattern of the public control of business has been woven. It expresses the general rule, against which other statutes are elaboration, qualification, exception, accommodation to circumstance.

Over the centuries this fabric of control has been woven. Public policy, the common law, usages of trade, statutes of the realm, opinion popular and unpopular, decrees of judges have all left their impress upon it. As industry has evolved, as necessities have become evident, as ways of thought have changed, the process has continued. The larger adjustment has been made by the legislature; the detail has been worked out by the courts. The law of industry is the cumulative result of countless expediencies shaped to countless occasions, a corpus distilled from myriads of decisions about everyday matters. Along a score of fronts its heritage of abstraction meets concrete situations and in the impact each is remade by the other. Its trim and tangled actuality is a product rather of the years than of intent. As a design it reveals a sprawling trimness, an order at peace with confusion, a surge towards diverse objectives. It has a beauty, a relevancy, an intricacy, an arresting quality which no blue print come to life could ever possess. Its logic is the logic of things that grow.

If one must be technical, the Sherman Act dates from I8go. The year marks the occasion upon which the ancient law received formal expression in a federal statute. Its translation from common law to Act of Congress was long overdue. As the national economy was transformed by the coming of the machine, the balance sheet, and the corporation, the pinch of transition was widely felt. A restriction of opportunity, a blocking of the channels of trade, an interference with the right of the individual to his calling became matters of common complaint. Farmers were per-

- B.A., r907, University of Texas; Ph.D., I913, University of Michigan; M.A. (hon.), 1928, Yale University. Professor of Law, Yale University School of Law, since 1928. Special Assistant to the Attorncy General, Antitrust Division, U. S. Department of Justice, since 1938. Member, National Recovery Administration, 1934-1935. Author of Current Economic Problems (1915, 1925); (with S. May) The Control of Wages (r923); (with H. R. Wright) The Case of Biruminous ConL (rg25); (with H. R. Wright) A Way of Order for Bituminous Coal (1928); (with D. Adair) The Power to Govern (1937); (with five associates) Price and Price Policies (1938). Contributor to legal and cconomic periodicals.

126 STAT. 209 (I 890$)$; 15 U. S. C. $\$ \$ 1-7$.

2 "As a charter of freedom, the Act has a generality and adaptability comparable to that found to be desirable in constitutional provisions." Hughes, C. J., in Appalachian Coals, Inc. v. U. S., 288 U. S. 344, 359 (1933). 
suaded that they were selling corn, hogs, wheat, cattle, tobacco, cotton to buyers who were acting in concert. Consumers were convinced that in the purchase of sugar, nails, copper, jute, cordage, borax, slate pencils, oil cloth, gutta percha, barbed wire fence they encountered "the thumbscrew of monopoly." The little feller knew for a certainty that he was being crowded to the wall by "the squeeze play," against which there was, or ought to be, a law.3 The Robber Barons, seizing the chance which mechanical invention had brought, were putting together their industrial domains. Such matters clearly lay beyond the competence of the several states; the Congress was continuously appealed to for a redress of grievances. All through the eighties the issue provoked increasing debate. By the Fifty-first Congress it was no longer to be denied.

In the Senate an act slowly took shape. $A$ number of bills-unlike in objective, substance, procedure, range, remedy-indicated the insistent demand for legislation. After long deliberation the Finance Committee reported favorably in amended form a bill introduced by Senator John Sherman. ${ }^{4}$ It declared "all arrangements, contracts, trusts, or combinations made with the intention "to prevent full and free competition" or "to advance the cost to the consumer" to be "against public policy, unlawful and void." It provided that any person "injured or damnified" by such an act might sue for and recover "twice the amount of the damages sustained and the cost of the suit." An addendum to the original measure conferred upon the circuit courts of the United States "original jurisdiction of all suits of a civil nature or at equity" which might result. It likewise directed the Attorney General and the several district attorneys "to prosecute all such cases to final judgment and execution."

For the real crusaders in the Senate this was far too mild a measure. Senator Reagan, of Texas, had gone trust-busting over the wide open spaces, and he thought he knew a criminal when he saw one. So, first as a substitute, later as an amendment, he offered his own bill. In rather severe terms it defined a "trust" as "a combination of capital, skill or acts" by which two or more persons "create or carry out any restrictions in trade"; made all persons who were parties to such a trust "guilty of a high misdemeanor"; and specified that each day tainted with a violation should be treated as a "separate offense." In like manner Senator Ingalls, conscious of the ills of the Great Middle West, proposed a substitute which he likewise converted into an amendment. In an elaboration of definition, penalty and detail it sought "the preventing and suppressing, so far as may be," of deals in futures in agricultural products. Although as substitutes they were unacceptable, as amendments they were welcome; and with a will the upper house added them to the measure before it. It quickly became apparent that two such tails were far too much for the original kite. Thereupon this omnibus act was recommitted-not to the Finance Committee whence the pristine measure had come-but to the Judiciary Committee.

Within six days the Judiciary Committee returned to the Senate the bill-or

\footnotetext{
${ }^{3} 2$ I CoNg. Rec., passim (1889).

${ }^{5}$ S. 1 , Calendar No. 14 , 5 Ist Cong., rst Sess. (r889).

- Ibid.

2 I CoNG. Rec. 96 (1889).
} 
rather a different bill. It had struck out all the lines that followed "be it enacted" and in their stead had written its own text. Vestiges survive in the remedies set down -the criminal action, the plea in equity, the private suit for damages. Otherwise the bill, disclaiming all novelty, does no more than recite for the federal jurisdiction the rules of the common law against restraint and monopoly. ${ }^{7}$ To many senators it was a matter of regret that the proposed draft was not addressed more particularly to "trusts," to "giant octopi," to "huge aggregates of capitalistic power" which were becoming a menace to "the comfort of ordinary life" and to "republican institutions." But the Judiciary Committee wanted to go warily "in entering upon a new and untrodden field of legislation." In undertaking to curb by national authority an evil which hitherto had been left to the states, it was loath to alter the established trends of legal tolerance. Senator Edmunds, for the Committee, explained that the intent was to make the "definition out of terms that were known to the law already." Senator Hoar-who drafted the measure that bears the name of his colleague from $\mathrm{Ohio}^{8}$ stated that "we have affirmed the old doctrine of the common law in regard to all interstate and international transactions." Later, in debate, he remarked, "the great thing that this bill does, except affording a remedy, is to extend to the federal jurisdiction the common law principles which protected fair competition in trade in old times in England."10

Thus the bill repeated, rather than created, the law. Its principle hailed from the days of petty trade, its intent was to impose upon business the rule of competition. Its focus is a term of art, "restraint of trade," which has a clear legal significance. Its lines of legality, its range of offenses, its prohibitions upon conduct are all those of the common law. Its formal declaration was deemed necessary only because Congress believed that there was no common law of the United States. A statute was necessary to establish for the federal jurisdiction sanctions which the several states enjoyed without formal enactment. The bill had vicissitudes which left not even a dent on its structure; and in the form in which it was re-reported-or more strictly, initially reported-it passed both houses, received the President's signature, and as "the Sherman Act" became the law of the land.

\section{II}

A word about its development will throw into relief the character and sweep of this rule against restraints. Although it dates from "time immemorial" it came into the law in the period marked by the break-up of the gilds. ${ }^{11}$ It is, like the enveloping policy of the freedom of trade, an aspect of the national protest against the exclusive

${ }^{7} \mathrm{Ibid}$.

${ }^{8}$ Senator George E. Hoar has said the act was called the Sherman Act for no other reason than that Senator Sherman "had nothing to do.with framing it whatsocver." 2 HoAr, AutoBiocrapHY of SEveNTY YeArs (1903) 363. It is worthy of note that to John Sherman, Senator from Ohio, the Sherman Act was the Silver Purchase Act.

2r Cong. Rec. 3146 (1890).

${ }^{10} 21$ CoNg. Rec. 3152 (1890).

${ }^{11}$ Note the authority of cases in Coke's Reports in the development of the doctrinc. Its close affinity to the cause in which the learned jurist was enlisted is not to be overlooked. Note the common law cases cited below. 
privileges enjoyed by these brotherhoods. In the law it was gradually elaborated out of judgments which emerged from actions brought under the ancient writs. At first the courts went no further than to refuse to entertain suits from persons who sought their help in creating or maintaining restraints. Thus a writ of trespass was refused to two schoolmasters who complained that a third had set up shop in competition with them; $;^{12}$ and an action for trespass on the case was brought by the Prior of Dunstable against a butcher, who instead of patronizing the Prior's market and paying the stall fee, sold meats on a market day in his house. ${ }^{13}$ In like manner a writ of debt sought by one John Dyer against a potential competitor who had obligated himself not to use "his art of a dyer's craft" within the town for half a year touched off the question of a restrictive covenant which ran against public policy. ${ }^{14}$ The writ of assumpsit was also held not to be available to one party who sought to hold another party to an agreement adjudged to be in restraint of trade. ${ }^{15}$ In time the courts refused to grant aid to the person seeking to enforce, and afforded a remedy to the person damaged by, a restrictive covenant. Thus out of such ancient writs, through acceptance or denial of causes of action, the doctrine of restraint emerged. The right to work became a fundamental tenet of the common law which a little later was declared to be above the King himself., ${ }^{18}$

The rule against restraints was not a creation of business enterprise. It took shape in a society dominated by petty trade. It came from days in which a pecuniary economy was in its early stages, the corporation little used, the techniques of acquisition still elementary, profits not yet an avowed end of adventure. The workaday world was still of the arts; the enterpriser, still a craftsman, was intent upon making a fair living for himself. ${ }^{17}$ Initially the rule had only a secondary concern with good, commodity, ware of trade. In a society ruled by handicraft, it is the skill of men of various trades which is of dominant concern at law and in public policy. The smith, the schoolmaster, the carrier, the barber-surgeon, plied their callings; the baker, the tailor, the dyer, the furrier received materials from their customers and to their "order" fashioned articles. The fabrication of wares for general sale in an impersonal market belonged to the future. The rule against restraints was an assertion that skills, occupations, mysteries, callings were affected with a public interest. $^{18}$

Little by little such initial steps were broadened into "the liberty of the subject to pursue lawful and established trades." At the common law "no man could be prohibited from working at any lawful trade, for the law abhors idleness, the mother

13 The Schoolmaster's Case, Y. B. Hen. IV, f. 47, pl. 2 I (14Io).

${ }^{23}$ The Meat Market Case, Y. B. Hen. VI, f. 19, pl. I3; f. 25, pl. 2 (1433).

¿4 Dyer's Case, Y. B. 2 Hen. V. f. 5, pl. 26 (1415).

${ }^{26}$ Note, among others, an Anonymous Case, Moore 115,72 Eng. Rep. 477 ( 1578 ), wherein a covenant by an apprentice not to engage in the craft of mercer in Nottingham for a period of four years was held invalid, and the Blacksmith's Case, 3 Leon. 2I7, 74 Eng. Rep. 643 (1587), where a bond given by one member of the fraternity to another not to ply his craft was held illegal.

${ }^{18}$ Statute of Monopolies, 2 I JAC. I, ch. $3(1623-24)$.

${ }^{17}$ Ashiney, Economic Organization of England (1928) 36.

${ }^{28}$ Darcy v. Allen, II Coke 84b, 77 Eng. Rep. 1260 (K. B. 1602). 
of all evil"; nor does the common law compel "the artificers and people of mystery" to "hold themselves everyone to one mystery" and "to no other than that which he has chosen." In fact the enjoyment of "a whole trade" by an individual is "malum in se," so contrary to the common law that it cannot be justified even by a royal patent of monopoly. ${ }^{20} \mathrm{~A}$ landmark in the creation of the rule involves the physician's calling. A patent granted by the King to the Royal College of Physicians in London had been confirmed by parliamentary act. Dr. Bonham, who had received a medical degree from the University of Cambridge, was refused admission to practice. Lord Coke found little difficulty in holding that the college had no legal authority to fine or imprison the learned doctor. His most significant reason was that Dr. Bonham was a competent physician, and the charter of the college, as confirmed by grant and statute, did not extend to the denial to a competent practitioner of his common right to the pursuit of his calling. ${ }^{21}$ This ruling that the common law fixes the bounds of royal prerogative has become a milestone along the road that led to the liberties guaranteed by the Constitution.

The Statute of Monopolies served to underline and to restate the rule against restraints. ${ }^{22}$ It professed to do no more than declare "the ancient and fundamental law" of the realm. It recited the ban of old against "the sole buying, selling, making, working or using of anything"; gave to any person or persons who might be "hindered, grieved, disturbed or disquieted" on pretext of a royal grant, a right of action for threefold the amount of the damages and double the costs; ${ }^{23}$ and provided that all such suits should be "forever hereafter examined, heard, tried and determined by and according to the common laws of this realm and not otherwise." In short, the Act gave a legislative statement to the rule against restraints, elevated the common law above the royal prerogative, and took from. the defense the right to plead a grant of monopoly in a suit at law. ${ }^{24}$

As in England petty trade gave way to commerce, the common right went along. Privilege had been the life blood of the gild merchant. Its dominant reason for being was to preserve trade to its members; its charter gave it power to exclude those who were not of the franchise. ${ }^{25}$ The craft gild, its successor, likewise by virtue of a charter from Crown or municipality, had and held the exclusive practice of an art, but the

${ }^{10}$ Case of the Tailors of Ipswich, Ir Coke 53a, 77 Eng. Rep. 1218 (K. B. 1614).

${ }^{20}$ Darcy v. Allen, II Coke 84 b, 77 Eng. Rep. 1260 (K. B. 1602).

${ }^{21}$ Plucknett, Bonham's Case and Judicial Review (1926) 40 Harv. L. Rev. 30; Corwin, The "Higher Law" Background of American Constitutional Law (1929) 42 Harv. L. Rev. 365; Thorne, Dr. Bonham's Case (I938) 54 L. Q. REv. 543.

22 The Statute of Monopolies, 21 JAc. I, ch. 3 (I623-24).

${ }^{23}$ Note the survival of the action in tort for "triple damages" in the Sherman Act. Note, too, that although "double" the loss might be recovered in private suit, it was not until Senator Hoar rewrote the bill in the idioms of the common law that the provision for triple damages appeared.

${ }^{24}$ The Statute of Monopolies was an act both against and for vested privileges. It had the support of those who wished to curb the grant of royal favors. It had also support from persons who wished to arrest further grants of letters patent lest they encroach upon their own privileges. In the act the declaration of the general rule against restraints is supplied with a formidable list of exceptions. These saving clauses extend to public bodies, to gilds of arts, trades and mysteries, and even to private individuals.

${ }^{25}$ Cheney, Introduction to the Industrial and Social History of ENGland (rev. ed. 1920) 5r, I Gross, The Gizd Merchant (1890) 43-50. 
fraternities were open to all who could meet their professional standards. Membership was granted to all who climbed the ladder of apprentice, journeyman and master. ${ }^{28}$ As the man from the next town ceased to be a foreigner, as Flemish weavers and continental chymists came over, as national control came to replace local regulation, the restrictions in apprenticeship and against artisans from out of town fell away, and the law made its response. By the middle of the sixteenth century a statute of the realm provided that "no person shall interrupt or deny any freeman carpenter, plasterer, joyner, hardhewer, sawyer, tiler, glasser, lime-burner; brick maker, plumber or laborer born in this realm or made denison to work in any of the said crafts in any city, borough or town corporate where he shall work nor be free of the same, any statute, law, ordinance or other thing to the contrary notwithstanding."27

Soon the courts were finding surviving privilege contrary to the ancient principles of the common law. In the classic case of the Comitas Sicissororum et Operorum. Panorum, ${ }^{28}$ letters patent from the King were not enough, and it was held that a qualified tailor, who had not received the gild's blessing, could not be kept from his occupation. Young men "ought in their youth ... to learn lawful sciences and trades. ... The common law abhors all monopolies, which prohibit any from working in any lawful trade." Apprenticeship is to be severely limited to its term of seven years. The holding of the defendant from the free practice of his trade for a longer period is "against the law . . . against the liberty and freedom of the subject . . . against the common law, and the commonwealth." ${ }^{\text {"g }}$

In a nation of shop-keepers the pursuit of a calling became a property protected against interference. "He that hinders another in his trade or livelihood is liable to an action for so hindering him."30 In time it became an inalienable right of an Englishman and eventually even a natural right of man. ${ }^{31}$ Today it is a commonplace for the courts of England to assert, against proscription by the Crown or collusion of individuals, "the common right of freedom of trade."32

\section{III}

The doctrine of "the common right" to the unmolested pursuit of a calling found an easy foothold in America. It was explicit in the corpus taken over from England and continental conditions tended to confirm and to strengthen it. It was an expres-

${ }^{20}$ I ASHLEY, ENGLish Economic History AND TheORY (1906) ch. II.

27 2 \& 3 EDw. VI, c. I5, \$4 (1548).

${ }^{28}$ Commonly known as the Tailors of Ipswich; supra note 19.

" 30 It is added, "Ordinances for the good order and government of men of trade and mysteries are good, but not to restrain any one in his lawful mystery." Id. at 54a.

${ }^{80}$ Keeble v. Hickeringill, i I East. 574n, 575n (1706).

${ }^{31}$ In France the skills of individuals werc lifted above gild control and freedom in their exercise was set within the order of nature itself. This ideology found expression in legislation. King Louis XVI's Edict of 1776 denied that "the right to work is a royal privilege which the King might sell and his subjects were bound to purchase from him." Indeed, "God in giving man want and desires rendering labor necessary for their satisfaction, conferred the right to labor upon all men, and this property is the first, most sacred of all."

s2 Attorney General of Australia v. Adelaide Steamship Co. [19r3] A. C. 78r, 794. 
sion of individual liberty, an aspect of the system of free enterprise, the very epitome of "the American way of thought." The Declaration of Independence declared "life, liberty, and the pursuit of happiness" to be the property of everyman. "When the Colonies separated from the mother country no privilege was more fully recognized or more completely incorporated into the fundamental law" than the right of the individual to "follow any of the known established trades and occupations of the country." ${ }^{33}$ In the various states of the Union callings were open to all who were willing to take their chances. The Great Republic was the land of opportunity.

The Fourteenth Amendment brought the common right into federal law. Here, as in England, it was first asserted against a formal grant of monopoly. A reconstruction legislature of Louisiana dominated by carpet-baggers had conferred upon a chartered company a monopoly in the slaughtering of cattle. The butchers, robbed of their occupation, appealed to the courts. In their behalf it was argued that the act of the state, by the denial of their right to their calling, had abridged their "privileges and immunities" as "citizens of the United States." ${ }^{34}$ The Court was unwilling as yet to go so far and by the closest of margins rejected the contention. But an issue had been raised which would not down and presently had to be decided all over. The butchers, whose plea had been rejected by the Court, appealed to the legislature and secured the repeal of the obnoxious charter. With fortunes of war and arguments reversed, it was this time the chartered company which appealed to the judiciary. ${ }^{85}$ Again "the opinion of the court" stood by the legislature. But two justices, who had dissented before, now concurred in the result. They argued, not that the second act of the legislature was valid, but that the first all along had been invalid. ${ }^{30}$ It would, however, not do to revive the rhetoric of privileges and immunities; so the common right of every man to his trade was tucked neatly away within the clause which forbids a state to deny or abridge life, liberty, or property, "without due process of law."

But two jurists, however bull-headed, are not a majority of a bench of nine. It took time, a shifting opinion and the proper cases to allow the doctrine to grow up. A classical economics which in the likeness of Newtonian physics made of industry an automatic self-operating mechanism was dominant. The common-sense of a pioneer nation united with the urges of a rising business community to impress upon public policy the philosophy of laissez faire. A transition from "status" to "contract" was in reputable belief the symbol of the march of mind and of culture. Because men were coming to think that way the views of two stubborn jurists were quoted by lesser judges as if they had been the opinion of the court. In due time the Court rebuked state officials who would deny to a heathen Chinee the privilege of carrying

${ }^{88}$ Field, J., dissenting, in Slaughter House Cases, 16 Wall. 36,105 ( 1873 ).

${ }^{34}$ The Slaughter House Cases, I6 Wall. 36 ( 1873 ). For the detailed development of this argument and the resulting doctrine, see Hamilton, The Path of Due Process, in READ, THE ConstTtution ReconSIDERED (I938).

${ }^{85}$ Butchers' Union Co. v. Crescent City Co., IIr U. S. 746 (I884).

${ }^{86}$ Field, J., concurring, id. at 754; Bradley J., concurring, id. at 760 . 
on the laundry trade. The "common right" at last had come into its own in the name of "the equal protection of the laws." trary and concurring brothers were accepted by the Court as canonical. ${ }^{38}$ As Mr. Justice Peckham quoted Mr. Justice Bradley, "the right to follow any of the common occupations of life is an inalienable right. It was formulated as such under the phrase 'pursuit of happiness' in the Declaration of Independence." With the same concurring opinion as authority, he identifies "the liberty of pursuit" with "the right to follow any of the ordinary callings" and makes it "a large ingredient in the civil liberty of the citizen." 39 In a gloss of his own Mr. Justice Peckham explains, "It is true that these remarks were made in regard to questions of monopoly, but they well describe the rights'to which are covered by the word. 'liberty' as contained in the Fourteenth Amendment." 40 The common right to a calling-harking back to ancient law and the Statute of Monopolies-becomes the sesame which opens the due process clause to judicial interpretation.

The invocation of the "common right" pointed the path for due process. It brought direction to groping justices, supplied a needed philosophy, and enabled the bench to breath life into a vague and inviting clause. In days of old the Crown was the principal source of monopoly; the legislature had now come into supremacy. Against the law-making body could be hurled a sanction which had been designed to keep the Stuart kings in their place. This sanction was the common law which Lord Coke, Parliament, and Acts of Settlement had elevated above the royal prerogative. In a country which grounded its legal system upon a written document, the ends it has been invoked to serve could be read into the Constitution itself. Yet the common right was no simple thing developing in isolation; it was an aspect of a system of usages, a symbol of an organized economy. For if the law accorded to one, it accorded to all, the right ot follow the trade of his choice. Crafts demand their land, their shops, their tools, and as they adopt the ways of business, the apparatus of production becomes elaborate. The freedom in respect to personal service has its corollary in a liberty in respect to property. Under a scheme of "individual initiative" freedom of contract fills the great office of drawing workmen and materials into production, keeping industries going, adjusting the supplies of various wares to the wants of men. Group is balanced against group, master against servant, lender against borrower, buyer against seller. The urge of the individual towards extravagant profits, excessive wages, stupendous bargains is held in check by others of his kind seeking the same advantage. In a word free competition is invoked to keep business going, absorb the shock of novelty, do justice between the parties. It was not privilege which Peckham, Brewer, Harlan, JJ., sought to enthrone. It was not property upon which they sought to confer the legal privilege of shaping the terms of the bargain. They professed, with little qualification, an economic creed;

\footnotetext{
${ }^{87}$ Yick Wo v. Hopkins, I 18 U. S. 356 (I886). $\quad{ }^{38}$ Allgeyer v. Louisiana, I65 U. S. 578 (1897).

${ }^{30}$ Id. at 589-590, quoting Bradley, J., concurring in Butchers' Union v. Crescent City Co., III U. S. 746,762 .

${ }^{10}$ Id. at 590 .
} 
and the empty receptacle of "due process" and the age-old vitality of "the common right" enabled them to read "free competition" into the Constitution. ${ }^{41}$

The sweep of doctrine appears in epitome in the famous bake-shop case. A statute of New York limited the hours of workers in bake-shops to ten in any one day. This act the Court, speaking through Mr. Justice Peckham, found to be a deprivation of liberty and property without due process of law. ${ }^{42}$ The rhetoric of the opinion is almost that of the law; the underlying logic, which directs the argument straight to its goal, is wholly that of economic faith. To the spokesman for the bench the state legislature is a irresponsible monarch; the statute-in-question, a grant of immunity; the bakers, the beneficiary of privilege. Upon all these the Court, armed with a statute of monopolies tucked away within the Fourteenth Amendment, righteously descends. The gist of the reasoning is that there is in the record not one scintilla of evidence to indicate that bakers are not like other men-adult males quite able to take care of their own interests in the bargaining process. To Mr. Justice Peckham, and the four brethren who were in agreement, the dominant point was the lack of a demonstration that in respect to the safeguarding of health the mechanism of free contract was not adequate. A youth of sixty-two had just come to the Court as Mr. Justice Holmes; and he, in probably the most famous dissent ever scribbled, supplied the text against which the opinion must be read. The "Constitution is not intended to embody a particular economic theory." 43 The majority of his brethren were unwilling to allow a state to usurp an industrial office which belonged to freedom of contract.

Some three years later the matter was even more sharply put. The depression of the nineties had witnessed a disastrous railroad strike. A Congressional intent that the incident should not be repeated found expression in a statute providing for an arbitration of differences upon interstate lines between masters and servants. ${ }^{44} \mathrm{~A}$ section designed to instrument the act forbade any carrier to discharge a workman because of his membership in a labor union. In a test case this provision was struck down by the Court in the name of "due process of law." "The freedom of contract" which Mr. Justice Peckham had found in the Fourteenth, was now discovered by Mr. Justice Harlan to lie within the Fifth Amendment..5 The spokesman for the Court was an enemy of privilege, an ardent trustbuster, a champion of the underdog. $\mathrm{He}$ had dissented in the bake-shop case, believing that bakers were in an unfavorable bargaining position, and citing statistics to clinch his point. ${ }^{40}$ In his mind the legal norm of the common right to a calling was reinforced by the prevalent opinion of the rural Kentucky in which he had grown up. So, for himself and his court, Mr.

"To capture the climate of opinion of the Court in the nineties read: Chicago, Milwaukee and St. Paul Ry. Co. v. Minnesota, 134 U. S. 418 (1890); U. S. v. E. C. Knight Co., 156 U. S. I (1895); U. S. v. Trans-Missouri Freight Ass'n, 166 U. S. 290 (1897); Smyth v. Ames, x69 U. S. 466 (1898); Allgeyer v. Louisiana, 165 U. S. 578 (1897).

${ }^{12}$ Lochner v. New York, 198 U. S. 45 (1905).

${ }^{48}$ Holmes, J., dissenting, id. at 75 . Note also evidence in the dissenting opinion of Harlan, J., that the issue had been decided on an economic theory.

"The Erdman Act, 30 STAT. 424 (1898). "E Adair v. U. S., 208 U. S. I6I (I908).

"Harlan, J., dissenting, in Lochner v. New York, 198 U. S. 45, 65 (1905). 
Justice Harlan expressed deep-seated convictions in a language which belonged alike to the ancient law, to the Constitution, to common sense, to sound economics. $\mathrm{He}$ declared that "the right of a person to sell his labor upon such terms as he deems proper is, in its essence, the same as the right of the purchaser of labor to prescribe the conditions upon which he will accept such labor." In the key of mutuality he continues, "so the right of the employee to quit the service of the employer, for whatever reason, is the same as the right of the employer, for whatever reason, to dispense with the services of such employee." And then crescendo he moves to his climax in universal statement, "In all such particulars the employer and the employee have equality of right, and any legislation that disturbs that equality is an arbitrary interference with the liberty of contract which no government can legally justify in a free land." 47 With the common law as sanction and an American individualist to wield the pen, the dogma of classical economics became the voice of the Constitution.

The common right, of course, could not control its own creation. Rules of law have the habit of asserting authority far beyond the sway of the reasons that call them into being. The ancient law that came into the "liberty" quickly passed on into the "property" of the due process clause. The Court which in the bake-shop case assumed the capacity of freedom of contract to do justice between the parties to industry presently neglected to look at the operation of competition. Then, as citations became available, the Court was content to invoke authority and ceased to need the support of economic theory. 48

Even within a few years a weakness in bargaining position ceases to be relevant 'or comes to be regarded as an attribute of property. The shift in reference from the system of free competition to the authority of "this Court" is clearly apparent in the Reports. Mr. Justice Holmes answers Harlan, not in the instant case, but when after the lapse of years the issue returns, "a workman not unnaturally may believe that only by belonging to a union can he secure a contract that shall be fair to him. . . If that belief, whether right or wrong, may be held by a reasonable man, it seems to me that it may be enforced by law in order to establish the equality of position between the parties in which liberty of contract begins." 49 To this Mr. Justice Pitney made instant retort, "No doubt, wherever the right of private property exists, there must and will be inequalities of fortune; and thus it naturally happens that parties negotiating about a contract are not equally unhampered by circumstances. . . . And, since it is self-evident that, unless all things are held in common, some persons must have more property than others, it is from the nature of things impossible to uphold freedom of contract and the right of private property without at the same time recognizing as legitimate those inequalities of fortune that are the necessary result of

\footnotetext{
${ }^{17}$ Adair v. U. S., 208 U. S. I6I, I74-5 (x908). Note that Roscoe Pound takes these sentences as his text in his classic article, Liberity of Contract (I909) I8 YALE L. J. 454.

${ }^{18}$ Compare with the earlier Lochner v. New York, 198 U. S. 45 (I905), or Adair v. U. S., 208 U. S. 16I (1908), the logic of Hitchman Coal and Coke Co. v. Mitchell, 245 U. S. 229 (19I7), and Duplex Printing Co. v. Deering, 254 U. S. 443 (Ig2I).

10 Dissenting in Coppage v. Kansas, 236 U. S. 1, 26-27 (1915).
} 
the exercise of those rights." ${ }^{\text {Jo }}$ After such a leap, citation would suffice for all needful reason.

The doctrine had drifted far from the reasons that had called it into being. It was no longer argued that the affairs of industry had best be left to freedom of contract between interested parties operating under a system of competition. Instead the disposition was to place the ordinary arrangements of business in a domain marked out by due process as beyond legislative control. The arrangements of the market place had now been committed into the rights of property. A doctrine derived from the law against monopoly became a check upon the police power of the state. A sanction invoked to outlaw privilege remained to enthrone it.

\section{IV}

So radical a position was not to be held. It was from the first compromised in the failure of the whole court to go along. The call to retreat was sounded long before the philosophy set down in dicta had been realized in holdings. In the very statement of a freedom of contract-now grounded in the equities of property rather than derived from the forces of competition-there were three sources of weakness rather too close to the surface of the dialectic to be kept hidden. The first was the instrumental character of the material out of which the theory of legislative impotence had been fashioned. Its underlying assumption was, not that business was not affected with a public interest, ${ }^{51}$ but that competition provided a system of regulation more effective than the government could devise. When agency was forgotten and competition degenerated into laissez faire, the edifice began to crumble. The second was that in invoking a usage of the ancient law, another usage of the ancient law was overlooked. As old as the right of the individual to his calling was the right of the state to regulate. It found expression in ordinance, assize, statute, in the judicial notion that price should be reasonable. In the concern of the government for health, safety, morals, a police power had been too deeply embedded in the law to be forgotten. The third was the curious paradox which attended the development of the due process. So long as the appeal was from the legislature to freedom of contract as an agency of social justice, the doctrine was functional. As soon as competition was forgotten, and freedom from legislative oversight became an attribute of property, the function was lost. The anti-monopoly germ came into due process as a doom upon immunity; in the refined doctrine it became a bulwark thrown about immunity. As circumstance changed, as a knowledge of the character of industrialism grew, as public opinion became sensitive to the evils of capitalism, the weaknesses in the structure of due process were laid bare.

${ }^{50}$ For the Court, $i d$. at 17 .

${ }^{52}$ One of the most curious of phenomena which attended the reading of laissez faire into constitutional law was the doctrine of public interest. An attempt, in respect to the power of the legislature over prices, to create a closed category of industries affected with a public interest was without cconomic foundation, rested upon historical error, and defied the rigidities of logic. For the high spots, compare Munn v. Illinois, 94 U. S. 113 (r877); Ribnik v. McBride, 277 U. S. 350 (1928); and Nebbia v. New York, 29r U. S. 502 (1934). 
An awareness of the character of industrialism found expression in an expanding oversight of industry. The needs of the people suggested, a growing public opinion demanded, the legislature accorded measures of amelioration. In respect to every statute, the persons to whom the act was distasteful fell back upon the judiciary as the ultimate line of defence. The courts with stern conviction rejected new-fangled laws; conducted arguments through intricate constitutional mazes, often of their own invention; joyfully placed their imprimatur upon novelties. But whatever the fate of an enactment the Constitutional ordeal had to be met. In a campaign that ran through many battles, the older sanction of the police power was set against a novel immunity in due process. In the struggle fortune was changeable; each doctrine had its crescendo and its diminuendo; a rapid surge might be followed by a violent reaction. But even judges of sternest convictions could not stand forever against the instant beat of an industrialism, too turbulent to give order, too violent to do justice between parties, headed it knew not whither. Legislation as an instrument of control might be checked; it could not be outlawed.

As act took its place beside act, the simple lines of the competitive design dominated the complicated pattern which emerged. There was no idea of abridging the common right to a calling, of denying freedom of contract, of deflecting "private enterprise" from its orbit. The thought was rather to adjust the system of competition to the shortcomings which experience had revealed. The norms of "fair" and "unfair" were evoked, and in the Clayton Act ${ }^{52}$ the Congress wrote, and in the Robinson-Patman $\mathrm{Act}^{53}$ revised, rules of the game for the competitive struggle. Industry is a concatenation of processes which must click together. If all its arrangements are at the mercy of a miscellany of individual agreements, the gears can never be made to engage. A concert can be secured only through some body of common understandings. In instances business may continue to do the trick itself, as it has with the standardization of parts, the continuance of market mechanisms, the invention of vocabularies for various trades. But, if it does not, the state must be called upon to make the cogs turn neatly together. Matters are often too deeply affected with a public interest for all the terms of the contract to be left to the private parties immediately concerned.

The body politic steps in to prescribe weights and measures, regulate hours of labor, ${ }^{54}$ impose employer's liability, ${ }^{55}$ prevent payments in script, ${ }^{56}$ prescribe minimum rates of wages. ${ }^{57}$ In conserving human resources it prohibits night work for women ${ }^{58}$ and outlaws child labor. ${ }^{59}$ In all such cases freedom of contract is set

62 38 STAT. 730 (rgI4); 15 U. S. C. $\$ \$ 12-27$ (1927).

E3 49 STst. 1526 (1936); 15 U. S. C. $\$ \$ 13$, 13a.

5t Bunting v. Oregon, 243 U. S. 426 (1917).

${ }^{26}$ Arizona Employers' Liability Cases, 250 U. S. 400 (1919).

${ }^{00}$ McLean v. Arkansas, 21 I U. S. 539 (Ig09).

${ }^{67}$ West Coast Hotel Co. v. Parrish, 300 U. S. 379 (1937).

${ }^{\mathrm{E}}$ Radice v. New York, 264 U. S. 292 (1924).

${ }^{10}$ There has never been any question of the right of the state to prohibit child labor. Doubts about the power of the federal government are now probably without foundation. If Hammer v. Dagenhart, 247 U. S. 25 I (1918), has nut been overruled, it seems clearly to have been outmoded. 
within a matrix of arrangements prescribed by authority. The lack of bargaining power on the part of weaker groups has been recognized. The protection of government has been accorded to trade unions ${ }^{60}$ and to farmers' cooperatives towards disposing of their services and products through an orderly process of collective bargaining. The aid of the government has been accorded to the milk ${ }^{01}$ and the bituminous coal ${ }^{62}$ industries to help competition over the hard places. A loss of foreign markets has played hob with the orderly growing of staple crops and the market has been unable to adjust production to a falling demand. Congress has come to the rescue with an agricultural adjustment act designed to effect stability in a period of rapid transition. ${ }^{63}$ It is only in respect to public utilities that the lines of control seriously depart from the competitive norm. Even there the competitive ideal is retained, and a commission is set up to safeguard the interests which free enterprise can no'longer serve. The topography of public control may be intricate; the detail of many designs may lie on its face. Yet in stark outline it still exhibits the bold lines of the competitive pattern.

Accordingly a simple rationale relates the Sherman Act to other statutes and draws various measures for the regulation of industry into an articulate whole. The hub from which the pattern of control radiates is the general rule against restraints. Its ban rests upon all persons; its prohibition lies against every act of the type at which it is aimed. It has no distinctive domain, no area of the national economy is exempt from its operation; the members of no class, caste, group are saved from its command. ${ }^{84}$ Like trespass, assault, deceit, wanton negligence, it is an offense of which any person may be guilty. The rule against restraints, like all wrongs recognized at common law, is universal in its sweep.

An exclusion from the rule against restraints is the kind of thing known to the common law as an immunity. Since time immemorial the authority of the King, Crown, State has been regarded as general. A privilege, perquisite, immunity, exception has always taken the form of a writing in which the "liberty" or "liberties" granted have in explicit terms been specified and defined. ${ }^{65}$ Even "ancient liberties" -dating far back, thoroughly established, quite unchallenged-were eventually com-

${ }^{80}$ National Labor Relations Bd. v. Jones \& Laughlin Steel Corp. 301 U. S. I (1937).

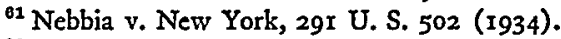

${ }^{2}$ Bituminous Coal Act of 1937,50 StaT. 72 (1937), 15 U. S. C. c. 17 B.

${ }^{63}$ See Mulford v. Smith, 307 U. S. 38, 42 (1939).

o4 "The Sherman Act is a broad enactment prohibiting unreasonable restraints upon interstate commerce, and monopolization, or attempts to monopolize, with penal sanctions." Hughes, C. J., in U. S. v. The Borden Co., 6o Sup. Ct. 182, 188 (1939).

${ }^{65}$ Note, for example, the liberty of the Prior of Dunstall, Y. B., II Hen. VI, f. 19, pl. 13; the crown grant of a market "with all liberties and free customs" pertaining thereto to "the abbey and convent of Ramsey," 2 Cartulariums, Monastari de Rameseia (R.S.) (1886) 298; the liberties of the merchant gild of Berwick-upon-Tweed, ToulmiN SMITh, ENGLISH GuILDS (1870) 338-346; the privilege and liberties of the College of Physicians of the City of London, Goodald, History op the College op Phystcinss of London. See Thorne, The Constitution and the Courts: a Reexamination of the Famous Case of Dr. Bonham, in READ, THE Constitution ReCONStPEREd (1938). 
mitted to parchment. Thus lords of the realm, ecclesiastical establishments, municipalities, fraternities, mysteries, colleges of physicians, honorable companies had each its distinctive prerogatives. As responsible government developed, the legislature replaced the Crown. Privilege, to be valid against or an exception to, the general law, had to be confirmed by Act of Parliament.

A concern to safeguard the rule against restraints was at the very heart of the movement towards statutory sanction. Here the creative period for Anglo-American law is the seventeenth century. From the accession of James I to the abdication of James II, royal provocation and legislative response, political act and military event, beat upon the Constitution to level ancient rights into a general law before which all men are equal. In this era the liberties of towns, fraternities, mysteries, individuals were transformed. The miscellany of specific perquisites within the commonwealth which the plural "liberties" connoted was converted into the abstract singular "liberty." This verbal receptacle-never sharply defined, never reduced to a list of particulars-came to provide a domicile for such liberties as belonged to all subjects and were consonant with the legal principle of equality before the law. Such liberties, now aspects of a large and more dominant "liberty," were grounded upon sanctions far more enduring than letters patent, a royal charter, or even a parliamentary statute. Before the century was done the particulars which make up liberty had become the inalienable rights of Englishmen. A century later they were definitely established in an order of nature as the rights of men. Meanwhile liberties-ancient or usurped -which could not be translated into universal rights had a strong presumption set over against them. Many were too deeply entrenched within the social fabric to yield at once to the demands of constitutional government. ${ }^{66}$ But such liberties came presently to be recognized as immunities. The royal pleasure, however explicit its manifestation, was no longer a lawful warrant. It was everywhere exposed to the general law. The will of the legislature was necessary to its security.

When the Sherman Act was being debated, it was understood that its prohibitions were personal and general; that exception and limitation are created only by legislative act. As the statute took shape, questions of the immunity of laborers and of farmers in respect to certain forms of collective activity were repeatedly raised. ${ }^{67}$ At one time an immunity was written into the bill in favor of a process of collective bargaining whose objectives were to lower hours and to raise wages. A similar amendment excepted farmers' cooperatives in activities concerned with "the primary scale of their products." ${ }^{38}$ As the current Act was shaped by the Judiciary Committee, they went down with the bill into which they had been incorporated.

\footnotetext{
${ }^{\circ 0}$ Note, for instance, the liberties preserved to towns, companies, and even individuals by the Statute of Monopolies.

${ }^{07}$ See e.g. 21 Cong. Rec. 2560-2562, 2565, 2571, 2606, 2654-2655, 2727, 2728 (r890).

o8 "That this act shall not be construed to apply to any arrangements, agreements, or combinations between the laborers, made with a view of lessening the number of hours of labor or the increasing of their wages: nor to any arrangements, agreements, or combinations among persons engaged in horticulture or agriculture made with a view of enhancing the prices of their own agricultural or horticultural products." S. I, as amended, 5Ist Cong., Ist Sess. (I890).
} 
As statute after statute has accommodated the competition pattern to the actualities of industry, exception has been by explicit grant. In every enactment the department from the rule against restraints has been severely limited. In object, activity, operation, the Act of Congress is held to its province; it is hedged about with precautions which keep it from becoming a general immunity. Thus the Webb Export Trade Act exempts from the charge of illegality under the Sherman Law "an association entered into for the sole purpose of engaging in export trade and actually engaged solely in such export trade." ${ }^{39}$ The Wagner Act, ${ }^{70}$ with trim lines and clear-cut intent, does not exempt trade unions from the prohibitions of the antitrust law. Instead it provides an orderly rubric for collective agreement about hours, wages and conditions of employment. Outside of the ordained procedure, which is subjected to the oversight of a regulatory body, the activities of laborers, even when done under trade union auspices, are subject to the general law. The statutes designed to insure to farmers fair prices are of similar kind. They offer protection in the primary sale of wheat, corn, cotton, hogs, dairy products. But they are drawn with a scrupulous regard for the objectives of the Sherman Act. The Capper-Volstead Act ${ }^{71}$ provides that "if the Secretary of Agriculture shall have reason to believe that such association monopolizes or restrains trade in interstate or foreign commerce to such an extent that the price of any agricultural product is unduly enhanced," he shall through the necessary steps of complaint, notice, hearing, and order cause it "to cease and desist from monopolization or restraint of trade." In the Agricultural Marketing Agreement $\mathrm{Act}^{72}$ the immunities granted are detailed, and the rule against restraints continues to fix the limits of tolerance. ${ }^{73}$ In the Fisheries Cooperative Marketing Act a similar power to proceed, if activities cross the line of legal tolerance, is granted to the Secretary of Commerce. ${ }^{74}$ In this sheaf of cooperative legislation, the power of initiation is conferred upon an official other than the Attorney General, but the ancient ban upon restraints is not relaxed.

In a number of instances where it is manifest that competition does not do the job, Congress has resorted to another type of regulatory device. Even before the Sherman Act was passed a commission was established for the regulation of the railroads. As the logic of the new arrangement became obvious, the carriers were relieved from the operation of the antitrust laws "in so far as may be necessary to enable them to do anything authorized or required" by an order of the Interstate Commerce Commission. ${ }^{75}$ It is of note that it was not until after the regulatory

\footnotetext{
69 There are the further provisions that "such association, agreement, or act is not in restraint of trade within the United States" and "such association does not, either in the United States or elsewhere, enter into any agreement, understanding, or conspiracy, or do any act which artificially or intentionally enhances or depresses prices within the United States." 40 STAT. 516, 517 (Ig18), 15 U. S. C. \$62.

${ }_{70} 49$ Stat. 449 (I935), 29 U. S. C. c. $7 . \quad{ }^{71} 42$ STAT. 388 (I922), 7 U. S. C. \$292.

72 50 STAT. 246,249 (1937), 7 U. S. C. $\$ \$ 608 \mathrm{~b}, 67 \mathrm{r}$ (d).

73 "The Agricultural Act is a limited statute with specific reference to particular transactions which may be regulated by official action in a prescribed manner. . . . If Congress had desired to grant any further immunity, Congress doubtless would have said so." Hughes, C. J., in United States v. The Borden Co., 60 Sup. Ct. I82, I88 (1939).

${ }^{74}{ }_{4}^{8}$ STAT. 1214 (1934), 15 U. S. C. $\$ 522$.

${ }^{75} 48$ STAT. 215 (1933), 49 U. S. C. $\$ 5(15)$.
} 
system had been fully matured that the verbal defenses of the Sherman Act were relaxed. ${ }^{76}$ Under the Shipping Act certain agreements are excepted from the Sherman Act; but it is unlawful to carry out such understandings without the approval of the Shipping Board, ${ }^{77}$ which has authority to accept, to reject, or to modify. Of like effect, and for reasons peculiar to the business, is the saving clause written into the Marine Insurance Association Act. ${ }^{78}$ In all such cases the public interest is as clearly and fully recognized as under the antitrust laws. But motor carriers, railroads, shipping, and things relating thereto, have ways of their own and places quite unique in the natural economy. So a public authority is set up the better to impose the public interest which a primitive competition seems powerless to promote.

A simple, definite, common-sense system of values shapes this series of measures which impresses a public policy upon the national economy. Its dominant principles are equality before the law and the common rule against restraints. There is, in the instance, much accommodation of requirements to the realities of the industrial order. But in the whole structure of legislation, there is little of recognized privilege or of immunity from the general law. The seeming exceptions, under examination, turn out to be no more than departures to effect adjustments of the common rule to distinctive circumstances. These departures fall roughly into two distinct classes: (I) the provision of some agency of public interest where circumstance renders competition an undependable instrument and (2) the indulgence of a limited collective activity to groups whose individual members are in a bargaining position inferior to that of the parties with whom they must deal. Laborers and farmers habitually accept contracts whose terms they have little power to shape. Legislation concerned with collective bargaining and cooperative marketing aims to help the worker and the farmer up to the plane upon which competition is presumed to do its work. But it is from such a plane that monopoly, combination, conspiracy reaches up after that which is illegal. The very statutes, which attempt to elevate weaker groups to the competitive plane, seek by the most express commands to hold them there. Rarely has a rule of the general law been so zealously guarded against exception and immunity.

\section{VI}

Thus was fashioned and fortified against immunities the legal ban on restraints. It dates from the period in which the supremacy of the law was asserted over the arbitrary will of the Crown. It is an instrument through which the royal pleasure was curbed, privilege fell before the common rule; all men-irrespective of class, caste, rank, wealth, profession, calling-were made equal before the law. The principle of "equal protection of the laws" has become an axiom of Anglo-American jurisprudence. It finds explicit statement in the Federal Constitution and the constitutions of the several states. It is embedded in the great corpus of the law reports. Its place in the structure of justice is far too obvious to invite elaboration or to demand citation.

\footnotetext{
${ }^{70}$ Note also similar provisions in the Motor Carrier Act, 49 Stat. 543 (1935), 49 U. S. C. $\$ 3 \mp 3 f$.

${ }^{27} 39$ Stat. 733 (1916), 46 U. S. C. $\$ 814$. ${ }_{48}^{71}$ Stat. 1000 (1920), 46 U. S. C. $\$ 885$.
} 
It is significant that a high place within the law was early accorded to the right to a calling. A man could not, with a threat to his livelihood or to the common good, barter it away. ${ }^{79}$ In protecting it against royal grant, monopoly or collusive conduct, he was entitled to his action. Once upon a time a gild, a university, a college of physicians, an honorable company, had its own system of police, with the rights of license, search and seizure, presentment and trial, fine and imprisonment, all the perquisites of effective discipline. Now the larger office has been taken over by the state, and in respect to trades, callings, occupations, fraternities, corporations, and even religious bodies, a private police is legally taboo. ${ }^{80}$ Men may freely band themselves in association, but their by-laws must not encroach upon the law of the land. The age of benefit of clergy is gone and an ancient privilege is not likely to be revived to the advantage of a more secular calling.

In the Sherman Act, as at common law, the offense is specified, but is not reduced to a catalogue of particulars. This is in accord with the spirit of an institution which aims to contrive instruments flexible enough to meet the demands for justice under shifting circumstances. Public policy must of necessity find expression in the most general terms. The objectives of the federal government are set down in a handful of prepositional phrases. The general objective of domestic legislation is "the common good" or "the general welfare." The police power, which keeps in order the affairs of a nation, aims at nothing more specific than public morals, public safety, public health. The provisions of the Sherman Act are written in the most general language, broad enough to meet all sorts of conditions, flexible enough to comprehend situations as they arise.

In every case hot from the affairs of business, the appeal is to the reasonable man. And with the reason of the common law-and its zone of discretion-the processes of justice cannot dispense. As time passes callings become businesses, occupations come and are gone, restraints alter in magnitude and character. To keep abreast of the times an industry undergoes constant revision in technology, organization, corporate structure, trade practices, marketing methods. To set down a prohibition as a detail of "thou shalt nots" is to stage an adventure into futility. Forbidden things will soon be done in unforbidden ways and presently the prohibitions apply only to

\footnotetext{
${ }^{70}$ An individual sells his trade, his business, his practice to another. The value of the assets which pass depends upon the withdrawal of the seller. He agrees not to resume his occupation within a specified area and over a certain span of years. A breach of contract provokes a suit which is met with a plea that the restrictive covenant is void as against public policy. In the cases the right of the individual to do as he will with his own is set over against the harm he thireatens to the public interest. The more rcplaceable the worker, the less skilled the occupation, the less of a necessity the commodity, the less strategic the industry, the more heavily the balance tips toward individual advantage. The more unique the craftsman, the more learned the mystery, the more necessary the service, the greater the compulsion. If an essential service to the community is at stake, a man cannot, of his own will and to his own advantage, bargain away his right to his trade. Leading cases are Mitchell v. Reynolds, I P. Wms. 181, 24 Eng. Rep. 347 (I7II); Hitchcock v: Coper, 6 Ad. \& E. 438, II2 Eng. Rep. I67 (1837); Union Strawboard Co. v. Bonfield, 193. Ill. 420, 6I N. E. I038 (Igor); Diamond Match Co. v. Roeber, ro6 N. Y. 473, 13 N. E. 419 (1887); Von Bremen v. MacMonnies, 200' N. Y. 4I, 93 N. E. 186 (1910); Oregon Steam Navigation Co. v. Winsor, 20 Wall. 64 (U. S. $x 873$ ).

${ }^{80}$ This is not to say that such systems of private police do not exist. Any student of industries or any attorney who has followed antitrust cases for a period of years can recite numerous examples.
} 
that which has ceased to be. As the national economy is transformed, such a procedure would quickly leave a wider and wider territory without the law. The general words of the act, with reason to direct, arrest and appoint limits, prevent the command from being frozen into obsolescence. The rule against restraints indicates clearly the type of activity to which tolerance is not to be accorded. As with other ordinances which announce policy, the application of the rule awaits the specific occasion. As the concrete issue is met, the antitrust law comes to grips with current reality.

The standard is definite enough to meet the requirements of justice. As with any other general rule, when the norm of restraint of trade is laid against a course of conduct, there are borderline cases. Here, because of the complicated character of the practices under review and the balance of values involved in judgment, they are often more than usually perplexing. But however difficult extreme cases may prove, the principles that should resolve them have been clearly proclaimed. Nor are they sheer abstractions for whose meaning public officials and courts must fumble. They have emerged from the concretions of litigation, out of a medley of human tangles, over a span of centuries. A contract which imposes a restraint upon trade may be upheld or struck down. If upheld the reason is, as stated by a wise judge years ago, "not because they are advantageous to the individual," but "because it is for the benefit of the public at large that they be enforced." 81 Or, as another able jurist has put it, the agreement is reasonable if "the restraint is such only as to afford a fair protection to the interests of the party in favor of whom it is given, and not so large as to interfere with the interests of the public."82 The state cannot allow private parties to bargain or conspire away the advantage which the community has in access to members of a calling or in a competition for its patronage.

The Sherman Act is thus in accord with the great American tradition. Callings are by law open to all; men have a right to buy and sell in a free and open market. Yet the competitive system is not the ultimate word in industrial order; nor is it a definitive answer to all the problems of the national economy. Already an elaborate structure of statutes testifies to its shortcomings in operation. It may be that in the near future we must seriously depart from its pattern to serve the public interest. But, even in modification and departure, the norm of social justice embodied in the rule against restraints may not cease to be a guide. In any venture into regulation every party has a right to insist that it be accorded an equivalent for the protection of the open market which he is called upon to surrender. In a world where the unknown crowds upon us, public policy can have no enduring ultimate. For. its guidance we may discover a more reasonable scheme of values than we now know. But until that time, the objectives of the common right and the Sherman Act must continue to direct. However the pattern of industrial government is modified, the ideal they embody will remain the reference for economic justice.

\footnotetext{
81 Baron Parke, in Mallan v. May, in Mees. \& W.; 653, 665, I52 Eng. Rep. 967, 972 (1843).

${ }^{82}$ Nordenfelt v. Maxim Nordenfelt \& Co. [1894] A. C. 535,567 .
} 